\title{
Hydraulic optimization of the flat solar collectors SUN 1 and the temperature gradient of the heat carrier in a system of connected solar units
}

\author{
Alexander Tunik ${ }^{1}$, and Mikhail Tolstoy ${ }^{1, *}$ \\ ${ }^{1}$ Irkutsk National Research Technical University, 664074, Lermontova str., 83, Irkutsk, Russia
}

\begin{abstract}
The article presents an analytical method for selecting the optimal technical performance of the heat exchanger for a flat solar collector, using meander-shaped heat-sensing tubes, which allow obtaining a higher value of the coolant temperature at the exit from the flat solar collector. Also, the article presents a technique for determining the temperature of the coolant at the exit from a flat solar collector and the possibility of its application in the design of solar heating systems. This technique will allow to determine the optimum and the maximum possible number of successively connected flat liquid helium collectors and, accordingly, to obtain effective design and technical solutions. The technique is based on the use of the empirical dependence of the coolant's temperature in the outlet branch pipe of a flat solar collector on the length of its heat-sensing tubes. The technique has been successfully applied in the study of heat-mass transfer processes in a new model of a flat solar collector being developed at the Department of Engineering Communications and Life Support Systems of the Irkutsk National Research Technical University. A comparative analysis of the measured values of the coolant temperature in the outlet branch pipe of the investigated reservoir with the values calculated using the empirical dependence presented in the article actually confirmed the adequacy of the presented technique with reference to one solar collector. The article shows results of calculating a system of consecutively connected collectors, which was conducted using the aforementioned technology.
\end{abstract}

Simultaneously with the development of renewable energy technologies, the methods of designing life support systems are improving [1-11]. However, these methods are not able to solve all the problems arising in the search for optimal design solutions. One such question concerns solar heat supply.

For the implementation of projects aimed at developing solar heating systems, continuous improvements of solar installations and systems are required [12-14]. One of the new methods for increasing the efficiency of flat liquid solar collectors is the use of elongated heat-receiving tubes. This solution allows increasing the temperature at the outlet from the solar power plant, which will increase the heating rate of the coolant and increase its

\footnotetext{
*Corresponding author: tolstoi@istu.edu
} 
efficiency. To place elongated tubes in a standard-sized reservoir housing of $1 \mathrm{~m} \times 2 \mathrm{~m}$, meander-shaped tubes.

To develop a new model of a flat solar collector with the use of metro-shaped heatreceiving tubes, it was necessary to choose the most efficient configuration of the heat exchanger. For this purpose, models of several technical solutions of the heat exchanger were constructed and a hydraulic analysis of each of them was carried out using the method of "Specific linear pressure losses," which, in turn, is based on the application of the DarcyWeisbach formula [15-18].

Technical Solution No. 1: a solar collector heat exchanger consisting of 6 copper meander tubes (Figure 1) with a diameter of $12 \mathrm{~mm}$ and a length of $5 \mathrm{~m}$ connected by copper tees of $22 \mathrm{~mm}$ in diameter.

The minimum flow rate of the Grundfos UPS 25-40 circulation pump (max flow rate 3 $\mathrm{m}^{3} / \mathrm{h}$ and a maximum head of $4 \mathrm{~m}$, costs from 6,000 rubles) was chosen as the design flow rate because of being one of the most widely distributed, inexpensive, and high-quality circulating pumps. The calculation is summarized in Table 1.

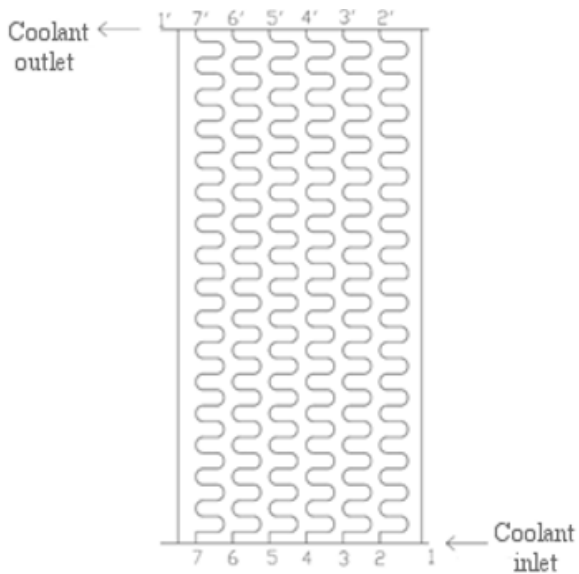

Fig. 1. Technical Solution No. 1: 6 meandering tubes, $4 \mathrm{~m}$ long and $12 \mathrm{~mm}$ in diameter, being connected by tees $22 \mathrm{~mm}$ in diameter.

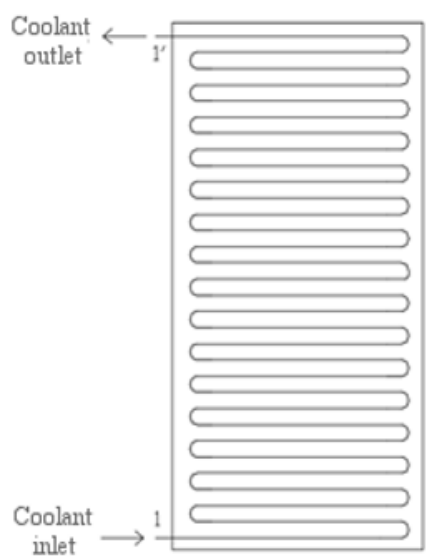

Fig. 2. Technical Solution No. 2: 1 - a meander-shaped tube, $31 \mathrm{~m}$ long and 12 $\mathrm{mm}$ in diameter.

Table 1. Hydraulic calculation of the heat exchanger (Technical solution No. 1).

\begin{tabular}{|c|c|c|c|c|c|c|c|c|c|c|}
\hline$\stackrel{\oplus}{=}$ & 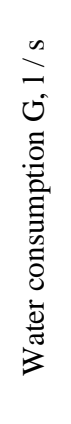 & 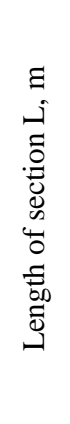 & 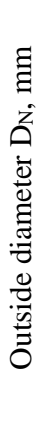 & 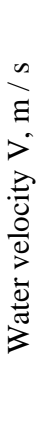 & 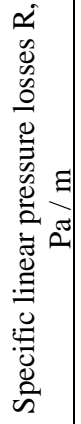 & 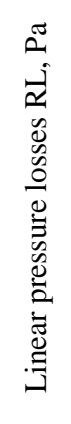 & 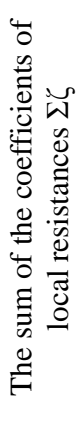 & 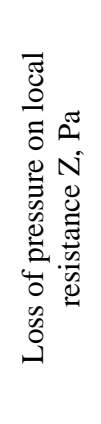 & $\begin{array}{l}\pi \\
0 \\
2 \\
0 \\
0 \\
0 \\
0 \\
0 \\
\vdots \\
0 \\
0 \\
0 \\
0 \\
0 \\
0 \\
0\end{array}$ & Notes \\
\hline 1 & 2 & 3 & 4 & 5 & 6 & 7 & 8 & 9 & 10 & 11 \\
\hline $1-2$ & 0,36 & 0,18 & 22 & 1 & 510 & 91,8 & 0,5 & 250,00 & 341,80 & $\begin{array}{c}\text { Tee per pass } \\
\zeta=0,5\end{array}$ \\
\hline
\end{tabular}




\begin{tabular}{|c|c|c|c|c|c|c|c|c|c|c|}
\hline $2-3$ & 0,30 & 0,16 & 22 & 0,95 & 490 & 78,4 & 1 & 451,25 & 529,65 & $\begin{array}{c}\text { Tee per pass } \\
\zeta=0,5 ; \text { Tee per } \\
\text { pass } \zeta=0,5 ;\end{array}$ \\
\hline $3-4$ & 0,24 & 0,16 & 22 & 0,75 & 300 & 48 & 1 & 281,25 & 329,25 & $\begin{array}{c}\text { Tee per pass } \\
\zeta=0,5 ; \text { Tee per } \\
\text { pass } \zeta=0,5 ;\end{array}$ \\
\hline $4-5$ & 0,18 & 0,16 & 22 & 0,5 & 170 & 27,2 & 1 & 125,00 & $152,20 \begin{array}{c}\text { Tee per pass } \\
\zeta=0,5 ; \text { Tee per } \\
\text { pass } \zeta=0,5 ;\end{array}$ \\
\hline $5-6$ & 0,12 & 0,16 & 22 & 0,3 & 100 & 16 & 1 & 45,00 & $61,00 \begin{array}{c}\text { Tee per pass } \\
\zeta=0,5 ; \text { Tee per } \\
\text { pass } \zeta=0,5 ;\end{array}$ \\
\hline $6-7$ & 0,06 & 0,16 & 22 & 0,1 & 29 & 4,64 & 2 & 10,00 & $14,64 \begin{array}{c}\text { Tee per pass } \\
\zeta=0,5 ; \text { Tee for } \\
\text { branch } \zeta=1,5 ;\end{array}$ \\
\hline $7-7{ }^{\prime}$ & 0,06 & 5,00 & 12 & 0,6 & 400 & 2000 & 21,7 & 3906,00 & 5906,00 & $\begin{array}{c}31 \text { double tap } \\
\zeta=0,7 ;\end{array}$ \\
\hline $7 '-1 '$ & 0,36 & 0,07 & 22 & 1 & 510 & 35,7 & 1,5 & 750,00 & 785,70 & $\begin{array}{c}\text { Tee for fusion } \\
\zeta=1,5 ;\end{array}$ \\
\hline
\end{tabular}

Hydraulic calculation show that the total pressure loss of such a heat exchanger is $0.8 \mathrm{~m}$. This means that the Grundfos UPS 25-40 circulating pump will spend only 25 watts of electricity to overcome this resistance and ensure optimum flow. In this case, at the pipe wall having the temperature of $80^{\circ} \mathrm{C}$, the following collector parameters could be obtained (Table 2):

Table 2. Operating parameters of the solar collector with the Technical solution No. 1.

\begin{tabular}{|c|c|c|}
\hline $\begin{array}{c}\text { Efficiency of a straight edge of } \\
\text { a rectangular profile, } \mathbf{F}\end{array}$ & $\begin{array}{c}\text { Heat transfer coefficient from } \\
\text { pipe wall to liquid, } \mathbf{h}_{\text {foi }}\end{array}$ & $\begin{array}{c}\text { Coefficient of reservoir } \\
\text { efficiency, } \mathbf{F}^{\mathbf{}}\end{array}$ \\
\hline 0,794 & 900,00 & 0,786 \\
\hline
\end{tabular}

With a coolant temperature at the collector inlet of $5^{\circ} \mathrm{C}$, a solar radiation power of 1000 $\mathrm{W} / \mathrm{m}^{2}$ and an ambient temperature of $25^{\circ} \mathrm{C}$ at the outlet, we obtain $8.32^{\circ} \mathrm{C}$.

Technical Solution No. 2 is a solar collector heat exchanger consisting of one copper meandering tube (Figure 2), with a diameter of $12 \mathrm{~mm}$ and a length of $31 \mathrm{~m}$. For the uniqueness criterion, the coolant flow rate was taken as the same. The calculation was summarized in Table 3.

The hydraulic calculation showed that the total pressure loss of such a heat exchanger was $13.6 \mathrm{mmwg}$. In this case, in order to overcome such resistance, a large circulation power will be needed, costing from 40,000 rubles to pay for the power of $60 \mathrm{~W}$.

In this case, at the pipe wall temperature of $80^{\circ} \mathrm{C}$, the following collector parameters will be obtained (Table 4). 
Table 3. Hydraulic calculation of the heat exchanger of the Technical solution No. 2.

\begin{tabular}{|c|c|c|c|c|c|c|c|c|c|c|}
\hline$\stackrel{\mathscr{V}}{:}$ & 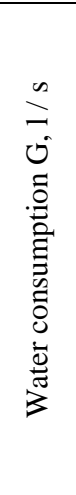 & 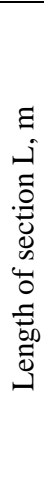 & 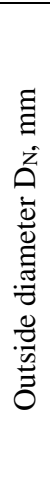 & 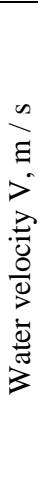 & 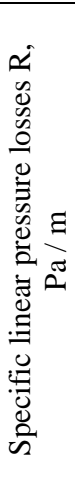 & 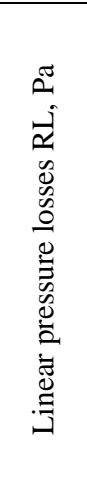 & 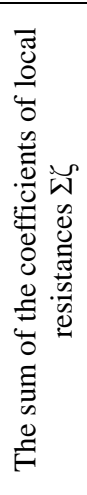 & 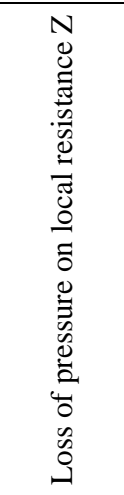 & 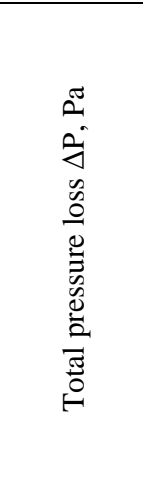 & Notes \\
\hline 1 & 3 & 4 & 5 & 6 & 7 & 8 & 9 & 10 & 11 & 12 \\
\hline \multicolumn{11}{|c|}{ Pipe diameter of $12 \mathrm{~mm}$} \\
\hline $1-1^{\prime}$ & 0,36 & 31 & 12 & 2 & 3000 & 93000 & 21,7 & 43400,00 & 136400,00 & $\begin{array}{l}31 \text { double } \\
\operatorname{tap} \zeta=0,7\end{array}$ \\
\hline
\end{tabular}

Table 4. Operating parameters of the solar collector with the technical solution No. 2.

\begin{tabular}{|c|c|c|}
\hline $\begin{array}{c}\text { Efficiency of a straight } \\
\text { edge of a rectangular } \\
\text { profile, } \mathbf{F}\end{array}$ & $\begin{array}{c}\text { Coefficient of heat transfer } \\
\text { from the pipe wall to the } \\
\text { liquid, hfoi }\end{array}$ & $\begin{array}{c}\text { Coefficient of collector } \\
\text { efficiency, } \mathbf{F}^{\prime}\end{array}$ \\
\hline 0,164 & 1345,10 & 0,170 \\
\hline
\end{tabular}

A large value of $\mathrm{h}_{\mathrm{foi}}$ is obtained, but the values of all other parameters are extremely low due to the fact that the edge of the collector in this case is the width of the collector as a whole.

With a coolant temperature at the collector inlet of $5^{\circ} \mathrm{C}$, a solar radiation power of 1000 $\mathrm{W} / \mathrm{m}^{2}$, and an ambient temperature of $25^{\circ} \mathrm{C}$, we get $9.62^{\circ} \mathrm{C}$ at the output.

Technical Solution No. 3: a solar collector heat exchanger consisting of a first meandering tube (Figure 3) with a diameter of $22 \mathrm{~mm}$ and a length of $25 \mathrm{~m}$. The calculation will be summarized in Table 4.

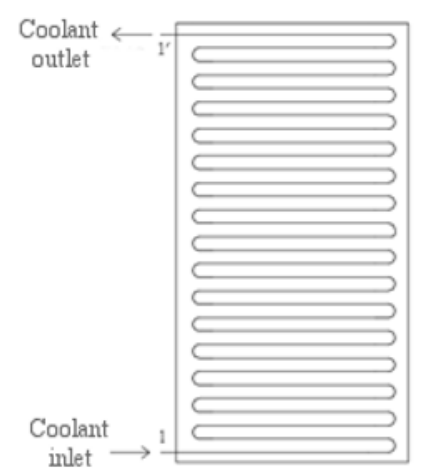

Fig. 3. Technical Solution No. 3: 1 - a meander-shaped tube being $25 \mathrm{~m}$ long and $22 \mathrm{~mm}$ in diameter. 
Table 4. Hydraulic calculation of the heat exchanger of Technical solution No. 3.

\begin{tabular}{|c|c|c|c|c|c|c|c|c|c|c|}
\hline$\stackrel{\mathscr{V}}{\mathscr{V}}$ & 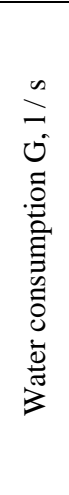 & 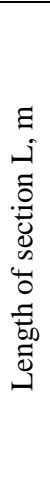 & 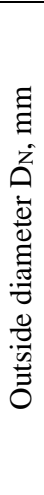 & 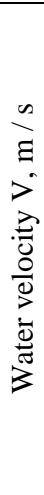 & 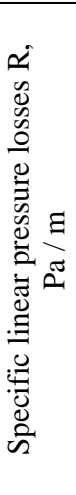 & 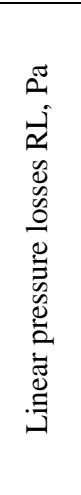 & 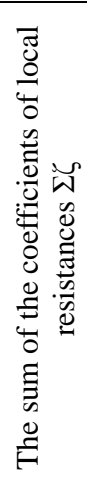 & 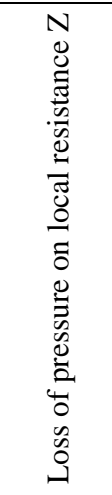 & 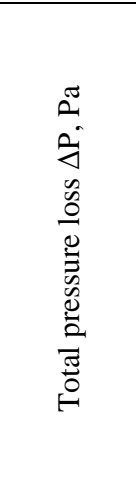 & Notes \\
\hline 1 & 3 & 4 & 5 & 6 & 7 & 8 & 9 & 10 & 11 & 12 \\
\hline \multicolumn{11}{|c|}{ Pipe diameter of $22 \mathrm{~mm}$} \\
\hline $1-1^{\prime}$ & 0,36 & 25 & 22 & 1 & 510 & 12750 & 17,5 & 8750,00 & 21500,00 & $\begin{array}{l}25 \text { double } \\
\text { taps } \zeta=0,7 ;\end{array}$ \\
\hline
\end{tabular}

At the same flow rate, the total pressure loss of this heat exchanger was $2.15 \mathrm{~m}$. In this case, to overcome this resistance, a Grundfos UPS 25-40 with a power consumption of 35 W. With a pipe wall temperature of $80^{\circ} \mathrm{C}$, we get the following collector parameters (Table $5)$.

Table 5. Operating parameters of the solar collector with the Technical solution No. 3.

\begin{tabular}{|c|c|c|}
\hline $\begin{array}{c}\text { Efficiency of a straight } \\
\text { edge of a rectangular } \\
\text { profile, } \mathbf{F}\end{array}$ & $\begin{array}{c}\text { Coefficient of heat } \\
\text { transfer from the pipe } \\
\text { wall to the liquid, } \mathbf{h}_{\text {foi }}\end{array}$ & $\begin{array}{c}\text { Coefficient of collector } \\
\text { efficiency, } \mathbf{F}^{\prime}\end{array}$ \\
\hline 0,166 & 770,61 & 0,179 \\
\hline
\end{tabular}

With a coolant temperature at the collector inlet of $5^{\circ} \mathrm{C}$, a solar radiation power of 1000 $\mathrm{W} / \mathrm{m}^{2}$, and an ambient temperature of $25^{\circ} \mathrm{C}$, we will receive $8.72^{\circ} \mathrm{C}$.

Technical solution No. 1 is a heat exchanger of a solar collector with a low hydraulic resistance and a sufficiently high coefficient of heat transfer from the pipe wall to the liquid and the efficiency coefficient. To operate a solar collector with such a heat exchanger, a Grundfos UPS 25-40 circulating pump, operating at 1 speed and consuming only $25 \mathrm{~W}$ of electricity, is needed. The cost of this pump is relatively low and ranges from 6,000 rubles. Low hydraulic resistance makes it possible to increase the heat transfer coefficient from the pipe wall to the liquid and, consequently, the efficiency factor by simply switching the pump $2(35 \mathrm{~W})$ or $3(45 \mathrm{~W})$ speed, without having to change the pump to a more powerful and expensive one. Also, this solution will allow to connect 2 solar collectors in series without the need to replace the pump. The cost of materials for manufacturing such a heat exchanger will be from 6,000 to 7,000 rubles. However, this technical solution, other things being equal, makes it possible to obtain the temperature of the coolant at the outlet from the collector by $1.3^{\circ} \mathrm{C}$ less than with the Technical solution No. 2 and by $0.4^{\circ} \mathrm{C}$ less than with the Technical solution No. 3 .

The hydraulic resistance of the heat exchanger with the Technical solution No. 2 requires the use of a more powerful and expensive circulation pump. The cost of this pump starts at 40000 rubles. If one needs to connect several reservoirs, a significantly more expensive 
pump is needed. In addition, because such a heat exchanger had a too large rib of a rectangular profile, the efficiency factor of the collector with such a channel would be very low. Therefore, in spite of the considerably larger length of the pipe, the temperature of the coolant at the outlet of the collector will be only $1.3^{\circ} \mathrm{C}$ more than at the Technical decision № 1, with other things being equal. Despite the low cost of materials for the manufacture of such a collector (about 6,000 rubles), the costs of the circulation pump are so high that it makes the use of such a heat exchanger economically unprofitable, despite the higher temperature of the coolant at the outlet of the collector. Reducing the length of the pipe would allow to obtain less hydraulic resistance and somewhat reduce the cost of the required circulating pump, but not so much that a low-power and low-cost pump could be used. In addition, the temperature of the coolant at the collector outlet will also decrease, making this option impractical.

Technical solution No. 3 makes it possible to obtain a heat exchanger with a much lower hydraulic resistance than with the Technical solution No. 2; however, the cost of materials for the heat exchanger thus increases by 2 times, in comparison with other technical solutions. In this case, to overcome this resistance, the Grundfos UPS 25-40 (35W) is needed. However, even with the consecutive connection of 2 collectors, there is a consequent need for a more powerful pump. In addition, the temperature of the coolant at the collector outlet is only $0.4^{\circ} \mathrm{C}$ than in the Technical Solution No. 1. These facts make the use of such a heat exchanger less expedient than with technical solution No. 1.

To obtain the coolant temperature optimum for use in heating and hot water systems, one solar collector is not always sufficient. Often a serial connection of collectors is used (Figure 4), which allows to obtain the desired temperature at the output from the final collector in a row. As a rule, the number of collectors in one row is limited by the hydraulic resistances of the entire system. However, it is not known how many sequentially connected solar collectors with a comparatively low hydraulic resistance are necessary to heat the coolant to the optimum temperature, and at what number of these solar collectors the temperature of the coolant will reach its maximum under certain climatic conditions.

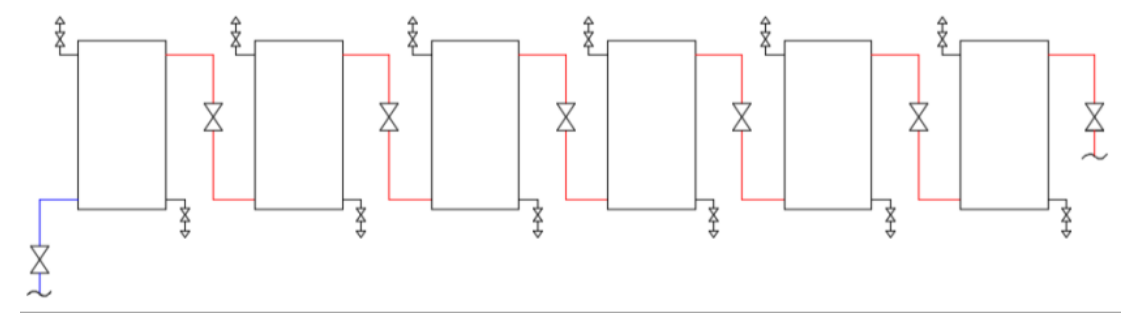

Fig. 4. A sequential connection of flat solar collectors.

When using flat solar collectors, it is possible to use the temperature dependence of the coolant at the exit from the flat solar collector $\mathrm{T}_{\mathrm{f}_{\mathrm{K}}}\left[{ }^{\circ} \mathrm{C}\right]$, expressed by the empirical formula (1), which was derived in [19] and has the form:

$$
\mathrm{T}_{\mathrm{f}_{\mathrm{K}}}=273-\mathrm{e}^{-\left[\mathrm{U}_{\mathrm{L}} \mathrm{FF}^{\prime} \mathrm{L} / \mathrm{mC}_{\mathrm{p}}\right]} \cdot\left(\mathrm{T}_{\mathrm{f}_{\mathrm{H}}}-\mathrm{T}_{\mathrm{a}}-\mathrm{S} / \mathrm{U}_{\mathrm{L}}\right)+\mathrm{T}_{\mathrm{a}}+\mathrm{S} / \mathrm{U}_{\mathrm{L}}
$$

where $\mathrm{U}_{\mathrm{L}}$ is the total coefficient of heat losses, $\mathrm{W} / \mathrm{m}^{2} \cdot \mathrm{K} ; W$ is the distance between the pipes of the collector, $m$; $F^{\prime}$ is the efficiency factor of the collector; $m$ is a coolant flow through one tube, $\mathrm{kg} / \mathrm{h} ; L$ is the length of solar collector tubes, $m ; \mathrm{C}_{\mathrm{p}}$ is the specific heat of the coolant, $\mathrm{W} /(\mathrm{kg} \cdot \mathrm{K}) ; \mathrm{T}_{\mathrm{f}_{\mathrm{H}}}$ is the temperature of the coolant at the inlet branch pipe of the collector, $\mathrm{K} ; S$ is the energy of the solar radiation absorbed by the surface unit, $\mathrm{W} / \mathrm{m}^{2} ; \mathrm{T}_{\mathrm{a}}$ is the temperature of the outside air, $\mathrm{K}$; $\mathrm{U}_{\mathrm{L}}$ is the total coefficient of thermal losses of the collector, $\mathrm{W} / \mathrm{m}^{2} \cdot \mathrm{K}$. 
This formula was used to study a new model of a flat solar collector, being called the Solar UNIT 1 or SUN 1 for short (Fig. 5) [20]. A patent for a utility model has been obtained for this collector [21]. This is the development of the scientists from the Department of Engineering Communications and Life Support Systems of the Irkutsk National Research Technical University (INRTU). Its main features include the reinforced rear heat insulation and double glazing, allowing the collector to save more thermal energy in cold weather conditions; meandering heat-absorbing tubes; low hydraulic resistance; maintainability, eliminating the need to completely replace it in the event of mechanical damage, as well as a relatively low price.

a)

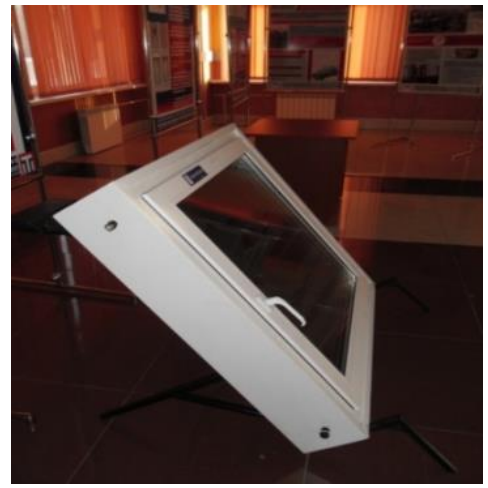

b)

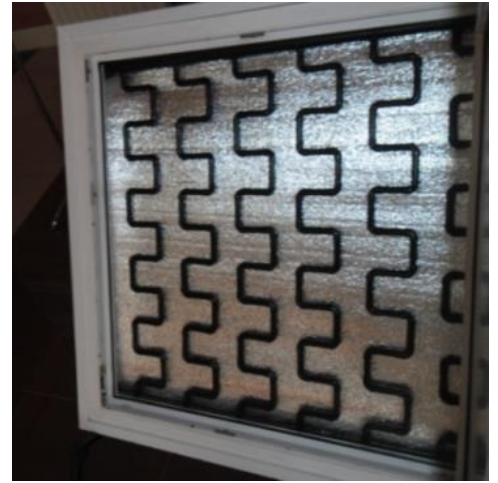

Fig. 5. a) The solar collector prototype SUN 1; b) meandering heat-receiving tubes of the collector SUN 1.

Comparison of the coolant temperature values at the outlet pipe of the solar collector SUN 1 being calculated using the formula (1) and the values obtained experimentally (Fig. 6) showed that the difference between them was not more than 5\%, which can be explained by the error of the instruments and calculations. This proves that formula (1) makes it possible to obtain very accurate calculated values of the coolant temperature at the outlet of a flat liquid solar collector.

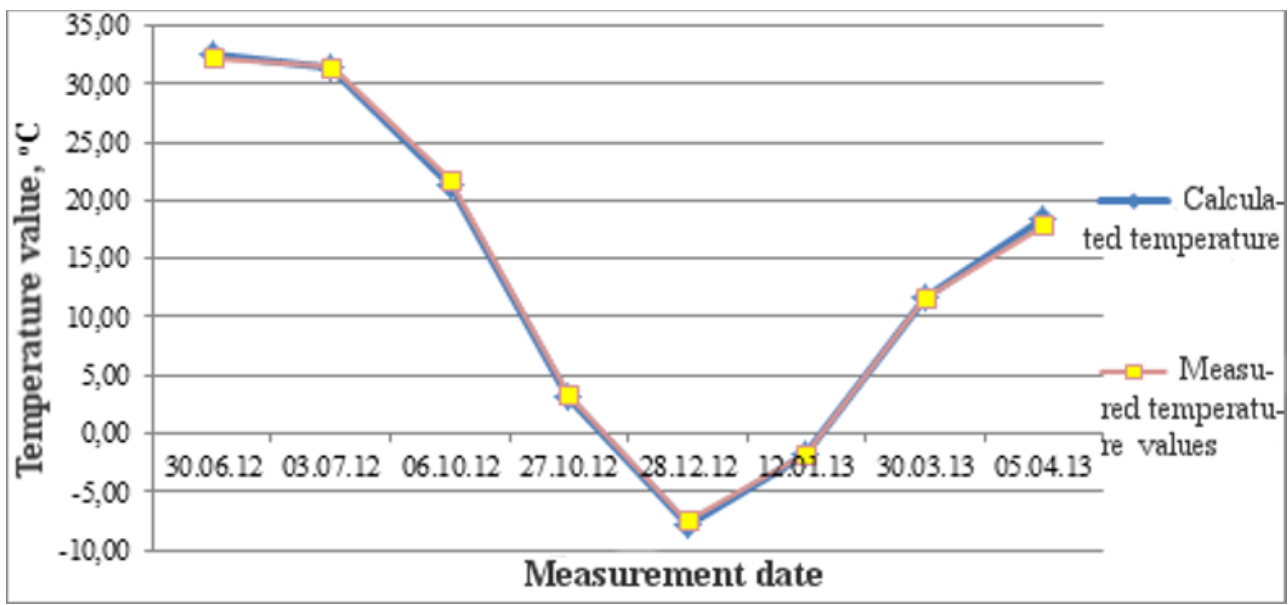

Fig. 6. A graph comparing the calculated and measured values of the coolant temperature at the outlet from the solar collector.

When designing a solar heating system in each project case, its optimal flow rate is selected to ensure the optimal heat exchange between two heat supply circuits. So, for 
example, for a system of a hypothetical object, a flow rate of $360 \mathrm{~kg} / \mathrm{h}$ is required. In this case, at a given flow rate, the hydraulic resistance will be about $0.1 \mathrm{mmwg}$.

The heat exchanger SUN 1 has the technical solution No. 1 (Figure 1), and the initial data is taken from Table 2 . With solar activity of $1000 \mathrm{~W} / \mathrm{m}^{2}$ at an ambient temperature of $25^{\circ} \mathrm{C}$ and using the formula (1), it was possible to obtain a trend in the temperature of the coolant at the outlet from solar collectors as they pass through a series of successively connected flat solar collectors (presented in Table 6).

Table 6. Changing the temperature of the coolant at the outlet from the solar collectors as they pass through a number of series-connected planar solar collectors SUN 1.

\begin{tabular}{|c|c|c|}
\hline $\begin{array}{l}\text { Number of solar } \\
\text { collectors in a row }\end{array}$ & $\begin{array}{l}\text { The temperature of the } \\
\text { coolant at the inlet to the } \\
\text { reservoir, }{ }^{\circ} \mathrm{C}\end{array}$ & $\begin{array}{c}\text { The temperature of the } \\
\text { coolant at the outlet from } \\
\text { the collector, }{ }^{\circ} \mathrm{C}\end{array}$ \\
\hline 1 & 5,00 & 16,70 \\
\hline 2 & 16,70 & 28,02 \\
\hline 3 & 28,02 & 38,98 \\
\hline 4 & 38,98 & 49,58 \\
\hline 5 & 49,58 & 59,84 \\
\hline 6 & 59,84 & 69,76 \\
\hline 7 & 69,76 & 79,35 \\
\hline 8 & 79,35 & 80,00 \\
\hline 9 & 80,00 & 80,00 \\
\hline
\end{tabular}

Thus, for a hot water supply system with a specified flow rate, it is sufficient to connect 6 solar collectors in one row. At the same time, taking into account the hydraulic resistance in the fittings and other pipe fittings that connect the collectors, the total pressure losses in the solar heat supply system will be comparatively low and amount to 1 to $1.5 \mathrm{~m}$. Art.

For clarity, it is shown that when adding solar collectors up to 8 items, the coolant temperature at the outlet from the collector continues to increase. However, adding 9 collectors is advisable, because the temperature of the coolant would not grow further. The calculation showed that the wall temperature of the pipe is $80^{\circ} \mathrm{C}$, and the heat carrier temperature at the collector inlet is the value of the coefficient of heat transfer from the pipe wall to the liquid, which means that the value of the efficiency coefficient turns out to be undefined (in view of the fact that in its formula there is a situation in which it is necessary to divide by 0 ), and consequently, the value of the coolant temperature at the output from the collector is also not determined. In this regard, we can conclude that, according to formula (1), the increase in the temperature of the heat carrier in a flat solar collector is limited by the temperature of the pipe wall.

The above calculation showed that the dependence expressed by formula (1) can be applied to the development of flat solar collectors and the design of solar heating systems. With respect to a system of several flat solar collectors being connected in series, the resulting physical model requires consideration of additional factors of influence, such as heat losses through connecting pipelines and fittings. This task will be solved in further studies.

\section{References}

1. B. Obama, Science, 55(6321), 126-129 (2017).

2. I. S. Gnatyuk, V. A. Butuzov, Innovations in Agriculture, 5(20), 130-135 (2016).

3. M. Z. Jacobson, M. A. Delucchi, En. Pol., 39(16), 1154-1169 (2011). 
4. S. K. Hoekman, A. Broch, C. Robbins, E. Ceniceros, M. Natarajan, Ren. and Sus. En. Rev, 16(1), 143-169 (2012).

5. S. A. Kalogirou, Progr. in En. and Com. Sc., 3(65), 231-295 (2004).

6. A. Mirzaei, F. Tangang, L. Juneng, Ren. En., 80, 17, 454-470 (2015).

7. M. M. Penchahpa, H. Malakooti, Ren. En., 111, 10, 1-10 (2017).

8. D. Connolly, H. Lund, B. V. Mathiesen, E. Pican, M. Leahy, Ren. En., 43(14,) 47-60, (2012).

9. P. Chatzitakisa, B. Dawoud, Ren. En., 110, 12, 47-58 (2017).

10. P. Bajpai, V. Dash, Ren. and Sus. En. Rev., 16(5), 2926-2939, (2011).

11. A. A. Tunik, M. Y. Tolstoy, IOP Conf. Ser.: Mat. Sc and Eng., 262, 6, (2017).

12. A. Jamar, Z. A. A. Majid, W. H. Azmi, M. Norhafana, A. A. Razak, Int. Com. in Heat and Mass Tran., 76, 10, 178-187 (2016).

13. A. Y. Alma, I. A. Lushkin, NGIEI Herald, 12 (43), 5-9 (2014).

14. V. S. Stepanov, I. I. Aizenberg, E. E. Baymachev, Heat supply news, 6 (10), 3, 34 - 36 (2001).

15. D. S. Voronkov, Proceedings of the Pskov Polytechnic Institute, 6, 99 - 104 (2009).

16. J. Krope, D. Dobersek, D. Goricanec, Proc. of the 2006 WSEAS/IASME Int. Conf. on Fluid Mech., 4, 59-62 (2006).

17. J. I. Sodiki, E. M. Adigio, AJER, 3(9), 91-96 (2014).

18. G. O. Brown, Env. and Water Res. His., 10, 34-43 (2002).

19. A. A. Tunick, MGSU Herald, 17, 126-142 (2016).

20. A. A. Tunik, Bulletin of the Irkutsk State Technical University, 3 (62), 101-105 (2012).

21. M. Yu. Tolstoy, N. V. Akinina, A. A. Tunik, Patent for Utility Model RU No. 112364 U1, F24J2 / 24 (2006.01), Solar Collector, Opobl. 10.01.2012. Bul. № 1 (Moscow, 2006).

22. I.A. Zuev, M.Yu. Tolstoy, A. A. Tunic, Proceedings of Universities. Investment. Construction. Real Estate, 4(19), 100-113 (2016) 